Indo. J. Chem. Res, 2020, 7(2), 170-176

\title{
KINETIKA KIMIA ANTIBAKTERI FRAKSI ALKANA ALIFATIK HASIL PIROLISIS CANGKANG BIJI JAMBU METE (CNS)
}

\section{Chemical Kinetics Antibacterial of Aliphatic Alkane Fraction from The Results of Pyrolysis Cashew Nut Shell (CNS)}

\author{
Rustam Musta ${ }^{*}$, Laily Nurliana ${ }^{2}$, Andraysno $^{1}$ \\ ${ }^{1}$ Chemistry Department, Teacher Training dan Education Faculty, Halu Oleo University, Kendari \\ ${ }^{2}$ Chemistry Department, Mathematic and Nature Science Faculty, Halu Oleo University, Kendari
}

*Corresponding author, e-mail: rustammusta04@gmail.com

Received: Oct. 2019 Published: Jan. 2020

\begin{abstract}
Chemical kinetics research antibacterial of aliphatic alkane fraction from the results of pyrolysis Cashew Nut Shell (CNS) (Annacardium occidentale L.) on Eschericia coli have been carried out. Cashew nuts are prepared by separating the shell and seeds for pyrolysis and purifying using a fractional distillation device. The results of $E$. coli anti-bacterial activity test from aliphatic alkane fractional distillation results of cashew nut shell pyrolysis products showed that the inhibitory power was different from each concentration variation of $100 \%, 75 \%, 50 \%$, $25 \%$, and $12.5 \%$, with inhibitor zone: $8.02 ; 7.16 ; 5.56 ; 4.52$ dan $4.26 \mathrm{~mm}$ which indicates that the inhibition is weak category for $12.5 \%$ and $25 \%$, medium category for $50 \%, 75 \%$ and $100 \%$. The clear zone that has been formed are calculated in terms of its chemical kinetics including the reaction order and the activity rate constant. The reaction order (n) antibacterial of aliphatic alkane fraction from the results of pyrolysis CNS on $E$. coli was 0.3145 with a constant activity rate of $(\mathrm{k})=1,7791$. Relation $\mathrm{A}_{\mathrm{t}}-\mathrm{A}_{0}$-t is expressed $\mathrm{A}_{\mathrm{t}}{ }^{0.7}=\mathrm{A}_{0}{ }^{0.7}-1,2 \mathrm{t}$ and $t_{1 / 2}=0,32 \mathrm{~A}_{\mathrm{o}}{ }^{0.7}$.
\end{abstract}

Keywords: Cashew nut shells, pyrolysis, aliphatic, E. coli, chemical kinetics.

\section{PENDAHULUAN}

Senyawa alkana yang terkandung dari bagian tumbuhan dapat digunakan sebagai antibakteri sebagaimana dilaporkan oleh Kanimozi (2012) tentang kandungan ekstrak etanol pada Coriandrum sativum L. Penelitian lainnya tentang aktivitas alkana sebagai antibakteri yaitu minyak atsiri Allium Nigrum L. (Rouis-Soussi, 2014) dan minyak atsiri kayu Kielmiera corieacea Mart \& Zucc. (Martins, 2015). Di lain pihak, penelitian tentang antibakteri $E$. coli dengan memanfaatkan bagian tumbuhan tertentu sebagai antibakteri telah banyak dilakukan antara lain aktivitas penghambatan $E$. coli dari ekstrak daun binara (Lia, 2017) dan ekstrak lamun (Septiani, 2017). Namun demikian, hal berbeda dilaporkan pada penelitian Suryati dkk. (2017) bahwa ekstrak Aloevera tidak memiliki daya hambat terhadap bakteri E. coli. Hal ini menunjukkan bahwa komponen tumbuh-tumbuhan tidak semuanya memberikan aktifitas antibakteri pada $E$. coli.

Limbah cangkang biji jambu mete atau Cashew Nut Shell (CNS) dapat dimanfaatkan cairan ekstraknya yang disebut Cashew Nut Shell Liquid (CNSL) (Saenap, 2016) yang mengandung senyawa asam anakardat, kardanol, kardol dan 2metil kardol (Towaha dan Nur, 2011). Pirolisis adalah suatu teknik alternatif untuk mendapatkan senyawa- senyawa dari CNS dengan dekomposisi kimia bahan organik melalui proses pemanasan tanpa oksigen, material mentah akan mengalami pemecahan struktur kimia menjadi fase gas (Wiraputra, 2017). Proses pirolisis menghasilkan produk berupa uap panas yang kemudian dikondensasi menjadi liquid (bio-oil), syngas (bio-gas) dan char (bio-arang) (Saenap, 2016). Pada proses ini, liquid (bio-oil) yang dihasilkan dari proses pirolisis diperkirakan masih mengandung tar yang kemudian harus dimasukkan ke dalam tungku destilasi. Dimana dalam proses destilasi, pemisahannya suhu pemanasan dijaga agar tetap konstan sehingga diperoleh destilat yang terbebas dari tar (Tima, 2016).

Kajian tentang antibakteri dapat dilakukan dengan meninjau berbagai sudut pandang antara 
lain pada Konsentrasi Hambat Minimum (KHM), $\mathrm{LC}_{50}$ dan signifikansi pengaruh anti bakteri tersebut. Khusus untuk pengaruh biasanya dilakukan dengan menggunakan uji statistik. Namun demikian masih ada cara lain untuk melihat pengaruh antibakteri terhadap bakteri yang diujikan yakni melalui pendekatan kinetika kimia. Kinetika kimia adalah suatu cabang ilmu kimia yang memberikan informasi mekanisme reaksi (Triyono, 1998). Dogra (1990) menyatakan bahwa kinetika kimia membahas antara lain laju, orde reaksi dan tetapan laju. Sebagai suatu hasil reaksi kimia, zona bening dapat dilihat sebagai efek reaksi dari antibakteri yang telah dikenakan pada suatu bakteri uji misalnya E. coli. Dengan demikian, aktivitas antibakteri fraksi alkan dan turunannya terhadap bakteri $E$. coli dapat dipandang sebagai suatu reaksi kimia yang perlu ditelaah mekanismenya dari sudut pandang kinetika kimia.

Penelitian sebelumnya tentang kinetika telah dilakukan yaitu penentuan konsentrasi minimum efektif minyak daun cengkeh pada penghambatan jamur Candida albicans yaitu sebesar 17,6\% (Musta, 2019) dan berdasarkan hal-hal tersebut di atas maka akan dilakukan kajian tentang Kinetika kimia antibakteri fraksi alkana dari hasil pirolisis CNS (Annacardium occidentale Linn) terhadap Bakteri E. coli.

\section{METODOLOGI}

Alat

Alat yang digunakan pada penelitian ini meliputi alat gelas seperti cawan petri, gelas ukur, gelas kimia, erlenmeyer, corong, alat destilasi semuanya merek (Pyrex), alat Kromatografi GasSpektrometri Massa (KGSM), inkubator, autoklaf (Wisecclave), waterbath (HWS24), timbangan analitik, kulkas laminar air flow cabinet, shaker incubator (Ratex), hot plate, lampu UV, spidol, mistar, tabung eppendorf, pipet ukur, oven, kawat ose, spritus, spatula, pipet tetes, botol vial.

\section{Bahan}

Bahan-bahan yang digunakan dalam penelitian ini adalah minyak hasil pirolisis pada penelitian sebelumnya (Nurliana, 2019), Escherichia coli ATCC 35219, amoxilin, pepton $2 \%$, agar $4 \%, 1 \% \mathrm{NaCI}$, minyak tween, akuades, kertas saring Whatman, plastik wrap, kasa, kertas label, kapas steril dan alumunium foil.

\section{Prosedur Kerja \\ Pemurnian Hasil Pirolisis CNS}

Hasil pirolisis CNS, diambil sebanyak 500 $\mathrm{mL}$, kemudian dimasukkan dalam wadah alat destilasi. Proses destilasi berlangsung sampai didapatkan fraksi. Kemudian hasil fraksi tersebut diidentifikasi dengan menggunakan alat KG-SM.

\section{Pengujian Aktivitas Antibakteri Sterilisasi alat dan bahan}

Seluruh alat dicuci bersih dan dikeringkan. Botol vial, tabung reaksi, erlenmeyer, cawan petri dibungkus dengan kertas. Kemudian semuanya disterilkan dengan autoklaf pada tekanan 121mpa selama 15 menit. Pengerjaan aseptis berlangsung dalam Laminar Air Flow yang sebelumnya telah dibersihkan dengan larutan alkohol $70 \%$, lalu proses sterilisasi dengan lampu UV yang telah menyala selama kurang lebih 1 jam sebelum digunakan dalam proses uji antibakteri (Sultana, 2014).

\section{Pembuatan dan Sterilisasi Media}

Medium yang digunakan untuk menumbuhkan mikroorganisme adalah Nutrient Agar (NA). Medium ini mengandung 2\% pepton, $1,5 \%$ yet ekstrak, $4 \%$ agar dan $1 \% \mathrm{NaCl}$. Dalam penelitian ini digunakan Nutrien Agar (Merck 2017) sebanyak 22,1 gr NA dilarutkan dengan $260 \mathrm{~mL}$ akuades dalam erlenmeyer, kemudian disterilkan menggunakan autoklaf pada tekanan $121 \mathrm{Mpa}$ (Daud, 2015)

Peremajaan mikroorganisme

Bakteri E. coli diremajakan dengan menginokulasi 2 ose $E$. coli, kemudian dimasukkan kedalam tabung reaksi yang berisi 10 $\mathrm{mL}$ media cair steril ( $2 \%$ pepton, $1,5 \%$ yeast estrak dan $4 \% \mathrm{NaCl}$ ) dan diinkubasi selama 24 jam (Daud 2015).

\section{Pengujian Aktivitas Antibakteri}

Media NA cair dipipet sebanyak $20 \mathrm{~mL}$, lalu dimasukkan dalam eppendorf kemudian ditambahkan $10 \mathrm{uL}$ inokulum bakteri E. coli dan dihomogenkan. Setelah homogen lalu dituang kedalam cawan petri dan diperlakukan dengan gerak melingkar agar media merapat pada permukaan cawan petri, selanjutnya didiamkan beberapa saat sampai memadat. Selanjutnya ditempatkan kertas cakram (berdiameter $0,5 \mathrm{~cm}$ ) yang telah direndam dalam larutan uji $(100 \%$ fraksi hasil pirolisis CNS, 75, 50, 25, dan 12,5\% serta minyak tween sebagai kontrol negatif, digunakan karena dipakai sebagai pelarut dalam 
Rustam Musta dkk. / Indo. J. Chem. Res., 2020, 7(2), 170-176

pengenceran dan amoxilin sebagai kontrol positif, digunakan karena merupakan antibiotic yang sudah lazim) pada permukaan media padat. Setelah itu, cawan petri ditutup rapat dan dibungkus dengan plastik wrap dan diinkubasi selama 1 x 24 jam pada suhu ruang lalu diukur zona hambat yang terbentuk (Bangjavicenna, 2008).

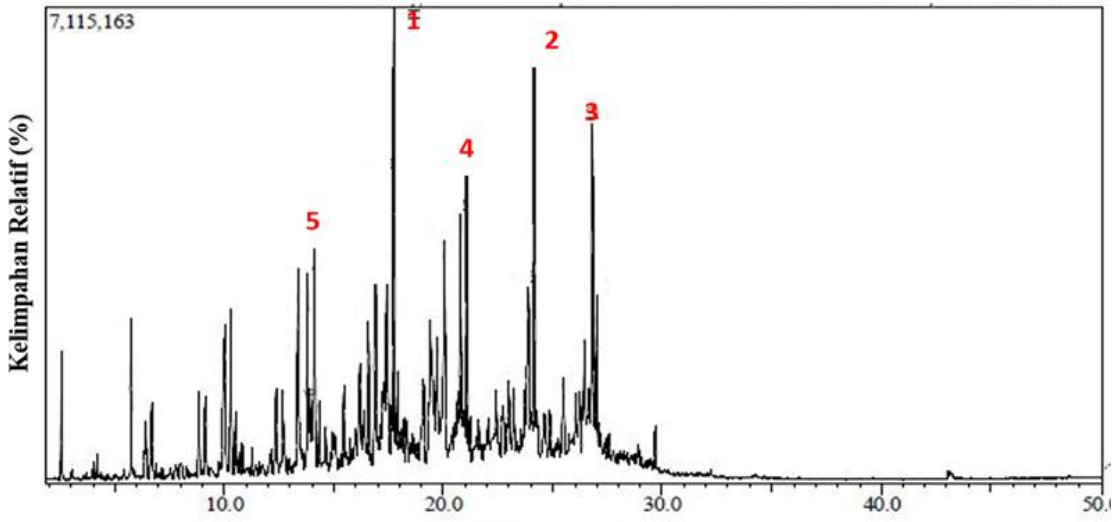

Gambar 1. Kromatogram fraksi alkana hasil pirolisis CNS
Hubungan ini menunjukkan bahwa laju pembentukan zona bening sebanding dengan laju reaksi dan karenanya akan hubungan seperti pada persamaan 2 .

$\mathrm{zb} \approx \mathrm{r}$
Tabel 1. Senyawa utama fraksi alkana hasil pirolisis CNS

\begin{tabular}{cccc}
\hline No & Nama senyawa & $\begin{array}{c}\text { Waktu } \\
\text { retensi } \\
\text { (menit) }\end{array}$ & $\begin{array}{c}\% \text { Luas } \\
\text { area }\end{array}$ \\
\hline 1 & Tridekana & 24.157 & 8.80 \\
2 & Undekana & 17.753 & 8.67 \\
3 & 1-Tetradekana & 26.803 & 6.91 \\
4 & Dodekana & 21.070 & 6.89 \\
5 & Dekana & 14.131 & 6.33 \\
\hline
\end{tabular}

\section{Pengolahan dan Analisis Data}

Data yang diperoleh antara lain data komponen senyawa utama anti bakteri hasil KGSM dan diameter zona bening. Data lainya berupa orde reaksi dan tetapan laju reaksi aktivitas antijamur yang diperoleh dari hasil pengolahan data menggunakan metode regresi linear yang diturunkan dari persamaan Dybkov (2013):

$$
\mathrm{r}=\mathrm{k}[\mathrm{A}]^{\mathrm{a}} \text {. }
$$

Laju reaksi (r) adalah besarnya peningkatan hasil reaksi atau penurunan konsentrasi reaktan setiap satuan waktu (Petrucci 1992). Sementara itu zona bening merupakan hasil reaksi antibakteri, yang diukur setelah masa inkubasi. Zona bening yang terbentuk meningkat dari waktu ke waktu. Zona bening yang terbentuk merupakan fungsi konsentrasi (Saeed, 2013).
Sehingga persamaan 2 dapat juga dituliskan seperti persamaan 3 .

$\mathrm{zb}=\mathrm{k}_{\mathrm{zb}} \mathrm{r}$

yang dapat dituliskan kembali menjadi persamaan 4.

$\mathrm{zb}=\mathrm{k}_{\mathrm{zb}} \mathrm{k}[\mathrm{A}]^{\mathrm{n}}$

dan disederhanakan menjadi:

$\mathrm{zb}=\mathrm{k}^{\prime}[\mathrm{A}]^{\mathrm{n}}$

akhirnya dengan menerapkan ln pada kedua sisi persamaan akan diperoleh persamaan 6 .

$\ln \mathrm{zb}=\ln \mathrm{k}+\mathrm{n} \ln [\mathrm{A}]$

Persamaan (6) dapat dibuat menjadi persamaan regresi linear: $y=a+b x$ yang berarti bahwa jika dibuat plot hubungan ln [A] terhadap ln zb maka akan diperoleh :

$$
\begin{aligned}
& \mathrm{a}=\ln \mathrm{k}^{\prime} \\
& \mathrm{k}^{\prime}=\mathrm{e}^{\mathrm{a}} \\
& \mathrm{b}=\mathrm{n}=\text { orde }
\end{aligned}
$$

Keterangan : $\mathrm{r}=$ Laju, $\mathrm{k}=$ Konstanta laju reaksi, $[\mathrm{A}]=$ Kosentrasi zat, $\mathrm{a}=\mathrm{n}=$ Orde reaksi, $\mathrm{zb}=$ diameter zona bening, $\mathrm{k}_{\mathrm{zb}}=$ tetapan 
pembentukan zona bening, $\mathrm{k}=$ tetapan laju reaksi dan k' merupakan konstanta untuk konsentrasi pada pembentukan zona bening yang merupakan gabungan $\mathrm{k}$ dan $\mathrm{k}_{\mathrm{zb}}$.

\section{HASIL DAN PEMBAHASAN}

\section{Identifikasi senyawa fraksi alkana hasil pirolisis CNS}

Gambar 1. menunjukan terdapat 20 komponen pada hasil KG-SM fraksi hasil produk pirolisis CNS dan terdapat 5 komponen utama sebagaimana ditunjukkan pada Tabel 1 .

\section{Uji Aktivitas Antibakteri $E$. coli fraksi alkana Hasil Pirolisis CNS}

Aktivitas antibakteri fraksi senyawa alkana hasil pirolisis CNS terhadap E. coli dapat ditunjukkan pada Gambar 7. Gambar tersebut menunjukkan bahwa berturut-turut untuk konsentrasi $100 \%, 75 \%, 50 \%, 25 \%$ dan $12,5 \%$ fraksi alkana hasil pirolisis CNS memberikan

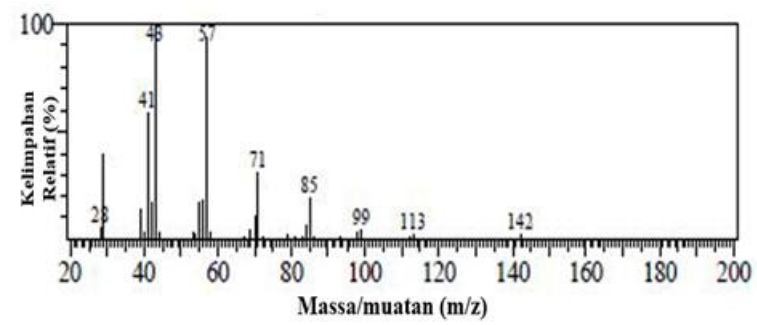

Gambar 2. Spektum massa senyawa dekana dengan waktu retensi 14.131 menit

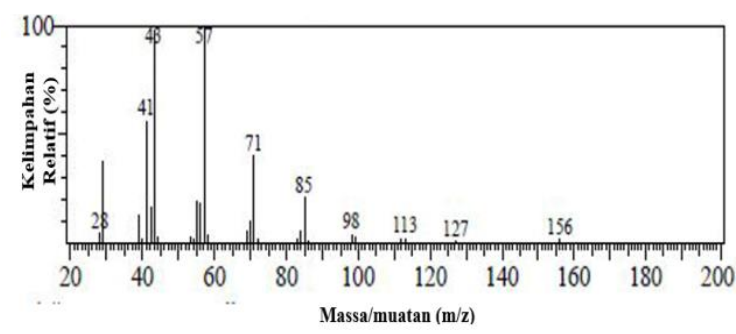

Gambar 3. Spektum massa senyawa undekana dengan waktu retensi 17.753 menit

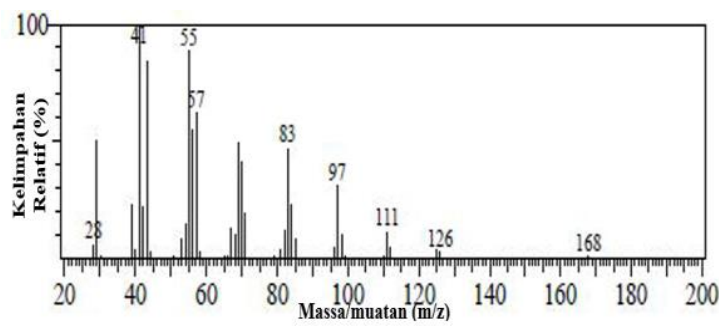

Gambar 4. Spektum massa senyawa 1tetrakana dengan waktu retensi 20.803 menit zona bening sebesar 8,$02 ; 7,16 ; 5,56 ; 4,52$ dan 4,26 mm.

Adapun kontrol posisif memberikan diameter zona bening sebesar 5,56 $\mathrm{mm}$ dan kontrol negatif tidak memberikan respon. Menurut Rastina et al., (2015), kriteria kekuatan daya hambat antibakteri dijelaskan berdasarkan parameter sebagai berikut: diameter zona hambat $5 \mathrm{~mm}$ atau kurang dikategorikan lemah, zona hambat 5-10 $\mathrm{mm}$ dikategorikan sedang, zona hambat $10-20 \mathrm{~mm}$ dikategorikan kuat dan zona hambat $20 \mathrm{~mm}$ atau lebih dikategorikan sangat kuat. Berdasarkan kriteria tersebut, maka diketahui bahwa fraksi alkana hasil pirolisis CNS untuk konsentrasi 12,5 dan 25\% masuk kategori daya hambat lemah sedangkan konsentrasi $50 \%$, $75 \%$ dan $100 \%$ masuk kategori daya hambat sedang.

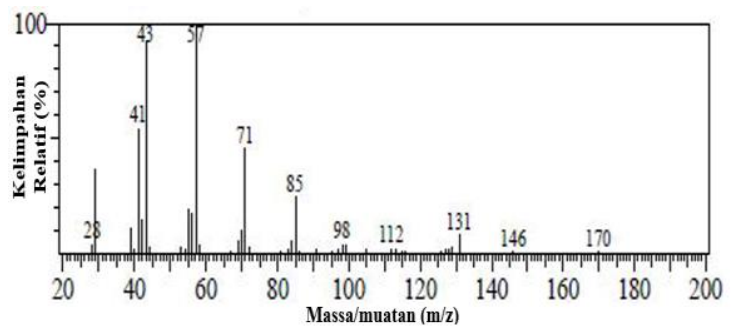

Gambar 5. Spektum massa senyawa dodekana dengan waktu retensi 21.070 menit

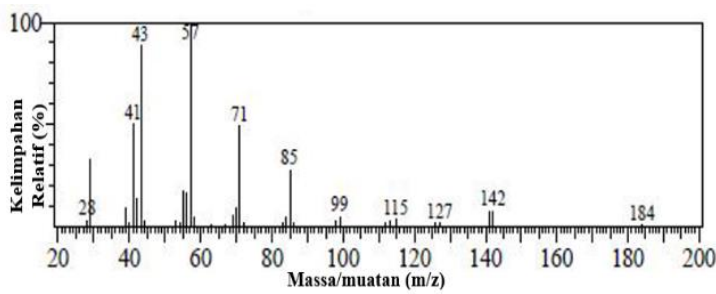

Gambar 6. Spektum massa senyawa tridekana dengan waktu retensi 24.157 menit

Kinetika Kimia Aktivitas Antibakteri E. coli fraksi alkana Hasil Pirolisis CNS

Gambar 8. memperlihatkan persamaan regresi linear yang diperoleh adalah $\mathrm{y}=0,3145 \mathrm{x}$ $+0,5761$ dengan $r^{2}=0,9176$. Hal ini memperlihatkan bahwa orde reaksi (n) senyawa alifatik hasil pirolisis CNS terhadap bakteri $E$. coli adalah 0,3145 yang terletak pada nilai orde (n) antara nol dan satu; dengan $\mathrm{k}^{\prime}=\mathrm{e}^{0,5761}=$ 1,7791 . Nilai $\mathrm{k}$, ini berlaku pada temperatur ruang yang dipilih dalam penelitian selama masa inkubasi yaitu 24 jam dengan dimensi satuan $\mathrm{mm}$. Dogra (1990) menyatakan bahwa apabila suatu reaksi berorde nol maka laju reaksinya tidak 
Rustam Musta dkk. / Indo. J. Chem. Res., 2020, 7(2), 170-176

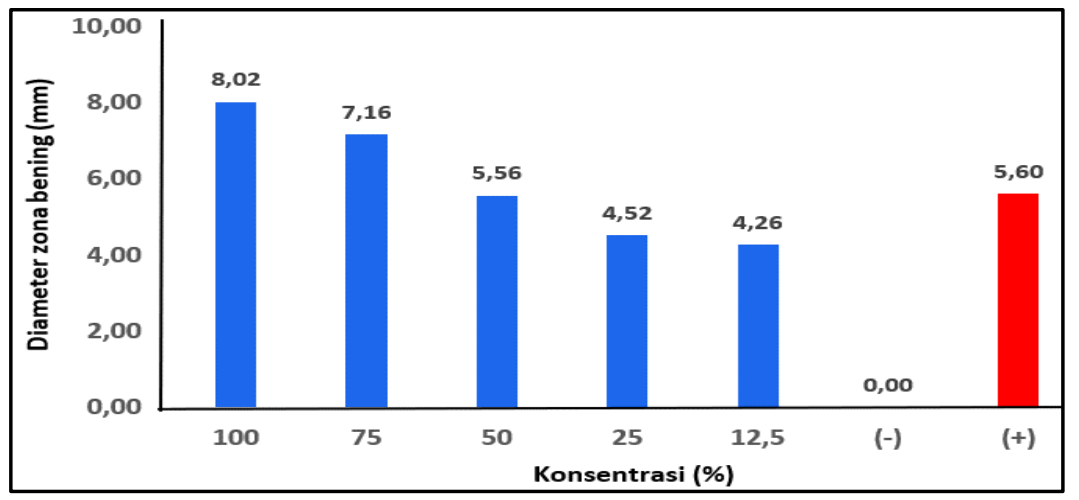

Gambar 7. Hasil uji aktivitas antibakteri fraksi alkana hasil pirolisis CNS

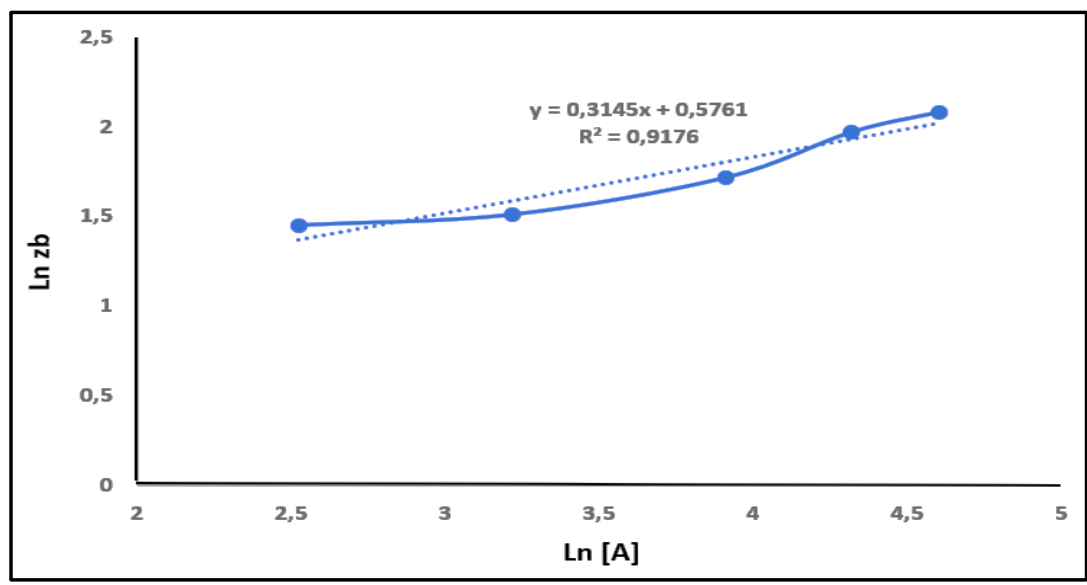

Gambar 8. Plot ln [A] vs ln zona bening

bergantung pada konsentrasi reaktan, sementara itu suatu reaksi yang berorde satu menunjukkan bahwa laju reaksi berbanding langsung dengan konsentrasi reaktannya. Triyono (1998) mengemukakan bahwa orde reaksi dapat berupa angka pecahan tergantung dari jenis reaksinya.

Laju reaksi dalam penelitian ini sebanding dengan zona bening ini, sehingga dapat dikatakan bahwa ada pengaruh konsentrasi senyawa alifatik hasil pirolisis CNS terhadap zona bening yang terbentuk sebagai indikasi daya hambat pada bakteri E. coli. Pengaruhnya dapat dilihat apa bila konsentrasi meningkat maka akan ada peningkatan zona bening sebesar pangkat 0,3145 . Dogra (1990) mengemukakan bahwa konstanta laju menggambarkan laju reaksi bila konsentrasi sebesar 1. Sehingga dapat diketahui bahwa apabila konsentrasi senyawa alifatik hasil pirolisis CNS sebesar $1 \%$ maka akan diperoleh zona bening sebesar $0,5761 \mathrm{~mm}$.

$-\frac{\partial \mathrm{A}}{\partial \mathrm{t}}=\mathrm{kA} \mathrm{A}^{\mathrm{n}}$

$$
\begin{aligned}
& -\frac{\partial \mathrm{A}}{\mathrm{A}^{\mathrm{n}}}=\mathrm{k} \cdot \partial \mathrm{t} \\
& -\int \frac{\partial \mathrm{A}}{\mathrm{A}^{0,1913}}=\int \mathrm{k} \cdot \partial \mathrm{t} \\
& -\int \frac{1}{\mathrm{~A}^{0,3145}} \partial \mathrm{A}=\int \mathrm{k} \cdot \partial \mathrm{t} \\
& -\int A^{-0,3145} \partial A=k \cdot t \\
& -\left(\frac{1}{-0,3145+1} A^{-0,3145+1} \int_{A_{0}}^{A_{t}}\right)=k t \\
& -\left(\frac{1}{0,6855} A^{0,6855} \int_{A_{0}}^{A_{t}}\right)=k t \\
& -\left(\frac{1}{0,6855} A_{t}{ }^{0,6855}-\frac{1}{0,6855} A_{0}^{0,6855}\right)=k t \\
& \frac{1}{0,6855} \mathrm{~A}_{0}^{0,6855}-\frac{1}{0,6855} \mathrm{~A}_{\mathrm{t}}^{0,6855}=\mathrm{kt} \\
& \frac{1}{0,6855}\left(A_{0}^{0,6855}-A_{t}^{0,6855}\right)=k t \\
& \mathrm{~A}_{0}{ }^{0,6855}-\mathrm{A}_{\mathrm{t}}{ }^{0,6855}=0,6855 \mathrm{kt} \\
& \mathrm{A}_{0}{ }^{0,6855}-\mathrm{A}_{\mathrm{t}} \mathrm{0}^{0,6855}=0,6855 \times 1,7791 \mathrm{t} \text {. } \\
& \mathrm{A}_{0}^{0,6855}-\mathrm{A}_{\mathrm{t}}^{0,6855}=1,2196 \mathrm{t} \\
& A_{t}^{0,6855}=A_{0}^{0,6855}-1,2196 t
\end{aligned}
$$

Jika $0,6855 \approx 0,7$ dan $1,2196 \approx 1,2$ maka dapat diperoleh hubungan yang lebih sederhana:

$\mathrm{A}_{\mathrm{t}}{ }^{0,7}=\mathrm{A}_{0}{ }^{0,7}-1,2 \mathrm{t}$ 
Hubungan At-Ao-t yang sudah diketahui dapat digunakan untuk menentukan waktu paruh dari reaksi senyawa alifatik hasil pirolisis CNS terhadap bakteri E. coli yaitu:

$\mathrm{A}_{\mathrm{o}}^{0,7}-\mathrm{A}_{\mathrm{t}}^{0,7}=1,2 t_{1 / 2}$

$\mathrm{A}_{\mathrm{o}}{ }^{0,7}-\left(\frac{1}{2} \mathrm{~A}_{\mathrm{o}}\right)^{0,7}=1,2 t_{1 / 2}$

$\mathrm{A}_{\mathrm{o}}{ }^{0,7}-\left(\frac{1}{2}\right)^{0,7}\left(\mathrm{~A}_{\mathrm{o}}\right)^{0,7}=1,2 t_{1 / 2}$

$\mathrm{A}_{\mathrm{o}}{ }^{0,7}-0,6156 \mathrm{~A}_{\mathrm{o}}^{0,7}=1,2 t_{1 / 2}$

$0,3844 \mathrm{~A}_{\mathrm{o}}{ }^{0,7}=1,2 t_{1 / 2}$

$t_{1 / 2}=\frac{0,3844}{1,2} \mathrm{~A}_{\mathrm{o}}^{0,7}$

$t_{1 / 2}=0,32 \mathrm{~A}_{\mathrm{o}}{ }^{0,7}$

Hal ini mengindikasikan bahwa waktu paruh dalam penghabatan bakteri E. coli oleh fraksi alifatik hasil pirolisis CNS ditentukan oleh konsentrasi awal.

\section{KESIMPULAN}

Berdasarkan hasil penelitian ini dapat disimpulkan bahwa senyawa fraksi alifatik hasil pirolisis CNS terdiri atas 5 senyawa utama yaitu Tridekana, Undekana, 1-Tetradekana, Dodekana dan Dekana dengan persen area berturut-turut: 8,$80 ; 8,67 ; 6,91 ; 6,89$ dan 6,33\%. Fraksi alkana hasil pirolisis CNS untuk konsentrasi 12,5 dan $25 \%$ masuk kategori daya hambat lemah sedangkan konsentrasi 50\%, 75\% dan 100\% masuk kategori daya hambat sedang. Orde reaksi (n) senyawa alifatik hasil pirolisis CNS terhadap bakteri $E$. coli sebesar 0,3145 dengan k' $=1,7791$ sehingga diperoleh persamaan $\mathrm{zb}=1,7791$ $[\mathrm{A}]^{0,3145}$ dengan persamaan untuk menghitung waktu paruh $\left(\mathrm{t}_{1 / 2}\right)=0,032[\mathrm{~A}]_{0}^{0,7}$. Adaptunun hubungan At-Ao-t dinyatakan dalam persamaan $\mathrm{A}_{\mathrm{t}}{ }^{0,7}=\mathrm{A}_{0}{ }^{0,7}-1,2 \mathrm{t}$.

\section{DAFTAR PUSTAKA}

Bagjavicenna, E., 2008, Potensi Propolis Lebah Trigona spp sebagai Bahan Antimikroba Ketombe, Skripsi, Biokimia, Fakultas MIPA Institut Pertanian Bogor, Bogor.

Daud, N. Z., 2015, Uji Aktivitas Anti Bakteri Kombinasi Ekstrak Etanol 70\% Kelopak Bunga Rosella (Hibiscus sabdariffa L) dan Daun Teh (Thea sinensis L) terhadap Staphylococcus aureus ATCC 25922, Jurnal Ilmiah Universitas Surabay, 4(2),1-15

Dogra, S.K., Dogra, S., 1990, Kimia Fisik dan Soal-Soal. UI Press. Jakarta
Dybkov V. I., 2013, Chemical Kinetics. IPMS Publications, Kyiv, Ukraine.

Kanimozi, D., Ratha, Bai, V.R., 2012, Analysis of Bioactive Components of Ethanolic Extract of Coriandrum Sativum L, IJRPS. 2(3), 97-110.

Lia, F., Ida, D.R., Silaban, S., 2017, Uji aktivitas antibakteri terhadap Escherichia coli dan antioksidan dari ekstrak air tumbuhan binara (Artemisia vulgaris L.), Jurnal Pendidikan Kimia (9)2,311-317

Martins, C.deM., Oliveira, A.de, do Nascimento E.A., Chang, R., Martins, C.H.G., da Silva, C.V., de Morais, S.A.L., Cunha, L.C.S., Moraes T.daS., and de Aquino, F.J.T., Martins, M.M., Rodrigues, P.V., 2015, Chemical Constituents and Evaluation of Antimicrobial and Cytotoxic Activities of Kielmeyera coriacea Mart \& Zucc, Essential Oils, Evidence-Based Complementary and Alternative Medicine. ID 842047, 1-9.

Musta, R., dan Nurliana, L., 2019, Studi Kinetika Efektifitas Minyak Daun Cengkeh (Syzygium aromaticum) sebagai Antijamur Candida albicans, Indo. J. Chem. Res. 6(2) ,107-111

Nurliana, L. dan Musta, R., 2019, Studi Kinetika Antibakteri dari Hasil Pirolisis Cangkang Biji Jambu Mete terhadap Staphylococcus aureus. Indo. J. Chem. Res. 6(2), 16-22.

Petrucci, R.H., 1992, Kimia Dasar Prinsip dan Terapan Modern. Alih bahasa: Suminar A. Edisi Ke-Empat, Jilid 2. Erlangga. Jakarta.

Rastina, Mirnawati S. dan Letje, W., 2015, Aktivitas Antibakteri Ekstrak Etanol Daun Kari (Murraya koenigii) Terhadap Staphylococcus aureus, Escherichia coli, dan Pseudomonas sp., Jurnal Kedokteran Hewan, 9(2), 185-188

Rouis-Soussi, L.S., Ayeb-Zakhama, A.E., Mahjoub, A., Flamini, G., Jannet, H.B., Harzallah-Skhiri, F., 2014, Chemical Composition and Antibacterial Activity of essential Oil from the Tunisian Allium ningrum L, EXCLI Journal, 13,526-535.

Saeed, M., Nadeem, M., Khan, M.R., Shabbir M.A., Shehzad, A., Amir, R.M., 2013, Antimicrobial Actifity of Syzygium aromaticum Extracts Againts Food Spoilage Bacterial, African Journal of Microbiology Research, 7(41),4848-4856.

Saenab, A., Wiryawan, K.G., Retnany dan Wina, E., 2016, Karakteristik Fisik dan Kimia dari 


\section{Rustam Musta dkk. / Indo. J. Chem. Res., 2020, 7(2), 170-176}

Produk Bioindustri Cangkang Jambu Mete (Annacardium occidentale L.), Jurnal Littri. 22(2),81-90

Septiani, Eko, N.D. dan Wijayanti, I., 2017, Aktifitas Antibakteri Ekstrak Lamun (Cymodocea rotundata) terhadap Bakteri Staphylococcus aureus dan Escherichia coli. Indonesian J. Fisheries Science and Technology, (13) 1,1-6

Sudijono, A., 2015, Pengantar Statistik Pendidikan. Rajagrafindo Persada. Jakarta

Sultana S, Shahidullah A.S.M, Islam M.dM., Wasey A.F.S.A. Nahar S., 2015, Antibacterial effect of Aqueous Neem (Azadirachta indica) leaf extract, crude neem leaf paste, and Ceftriaxone against Staphylococcus aureus, Escherichia coli and Pseudomonas aeruginosa, Malays. J. Med.Bio.Res., 2(2), 89-100.

Suryati, N., Bahar, E., Ilmiawati., 2017, Uji Efektivitas Antibakteri Antibakteri Ekstrak Aloe vera Terhadap Pertumbuhan Escherichia coli secara In Vitro, Jurnal Kesehatan Andalas, 6(3),518-521.

Tima, S.T., Yopi, Ifa, L., 2016, Pemanfaatan Asap Cair Kulit Biji Mete sebagai Pestisida, Journal of Chemical Proses Engineering. (1) 2,16-22.

Towaha, J. dan Nur, R.A., 2011, Pemanfaatan Cashew Nut Shell Liquid Sumber Fenol Alami pada Industri. Buletin RISTRI, 2(2), 187-198

Triyono, Bambang, S. dan Iqmal, T., 1998, Buku Ajar Kinetika Kimia. Jurusan Kimia FMIPA UGM, Yogyakarta.

Wiraputra, A.F., 2017, Pengaruh Pyrolysis NonIsothermal Terhadap Kualitas Bio-Oil Dari Sampah Real Kota Bandar Lampung, Skripsi, Jurusan Teknik Mesin Fakultas Teknik Universitas Lampung.

Riani, E., Y. Sudarso, M. R. Cardova., 2014, Heavy Metals Effect on Unviable Larvae of Dicrotendipes simpsoni (diptera: Chironomidae), A Case Study from Saguling Dam, Indonesia. Aquacultur, Aquarium, Conservation and Legislation (AACL), Inter. J. Bioflux Soc., 2(7), 76-84.

Riani, E., 2015, The Effect of Heavy Metals on Tissue Damage in Different Organs of Goldfish Cultivated in Floating Fish Net in Cirata Reservoir, Indonesia, PARIPEX - Ind. J. Res., 4(2), 54-58.
Rifardi., 2008, Deposisi Sedimen di Perairan Laut Paya Pesisir Pulau Kundur-Karimun-Riau, Ilmu Kelautan, 13(3), 147-152.

Schwarzenbach, R.P., Escher, B.I., Fenner, K., Hofstetter, T.B., Johnson, C.A., Von Gunten, U., Wehrli, B., 2006, Review: The Challenge of Micropollutans in Aquatic Systems, Science, 313 (5790), 1072-1077.

Setiawan, H., 2014, Pencemaran Logam Berat di Perairan Pesisir Kota Makassar dan Upaya Penanggulangannya, Info Teknis Eboni, 11(1), 1-13.

Strokal, M., Kroeze, C., 2013, Nitrogen and Phosphorus Inputs to the Black Sea in 19702050, Reg. Environ. Change 13, 179-192.

Sudirman, N., S. Husrin, Ruswahyuni., 2013, Baku Mutu Air Laut Untuk Kawasan Pelabuhan dan Indeks Pencemaran Perairan di Pelabuhan Perikanan Nusantara Kejawanan Cirebon, J. Saintek Perikanan 9(1), 14-22.

Supriyanti C, Zainul Kamal, Saman., 2008, Analisis Cemaran Logam Berat $\mathrm{Pb}, \mathrm{Cu}$ dan Cd Pada Ikan Air Tawar Dengan Metode Spektrofotometri Serapan Atom (SSA). Seminar Nasional III SDM Teknologi Nuklir, Yogyakarta.

Suwarsito, E. Sarjanti, 2014, Analisa Spasial Pencemaran Logam Berat pada Sedimen dan Biota Air di Muara Sungai Serayu, Kabupaten Cilacap, Geoedukasi, 3(1), 30-37.

Testa, J.M., Brady, D.C., Di Toro, D.M., Boynton, W.R., Kemp, W.M., 2013, Sediment Flux Modeling: Nitrogen, Phosphorus and Silica Cycles. Estuarine, Coastal and Shelf Sci., 131, 245-263.

Yang T., Liu Q., Chan L., and Liu Z., 2007, Magnetic Signature of Heavy Metals Pollution of Sediments: Case Study from the east Lake in Wuhan, China. J. Environ. Geology, 52(8), 1639-1650.

Yu, X., Y. Yana, W. Wang., 2011, The distribution and speciation of trace metals in surface sediments from the Pearl River Estuary and the Daya Bay, Southern China, Marine Pollution Bull., 60(8), 1364-137. 